\title{
Can we learn from eugenics?
}

\author{
Daniel Wikler University of Wisconsin, USA
}

\section{Abstract}

Eugenics casts a long shadow over contemporary genetics. Any measure, whether in clinical genetics or biotechnology, which is suspected of eugenic intent is likely to be opposed on that ground. Yet there is little consensus on what this word signifies, and often only a remote connection to the very complex set of social movements which took that name. After a brief historical summary of eugenics, this essay attempts to locate any wrongs inherent in eugenic doctrines. Four candidates are examined and rejected. The moral challenge posed by eugenics for genetics in our own time, I argue, is to achieve social justice.

(Fournal of Medical Ethics 1999;25:183-194)

Keywords: Eugenics; genetics; ethics; justice

\section{Eugenics yesterday and today}

The word "eugenics" may be unfamiliar to most people today, but for a period of about sixty-five years, roughly 1880 to 1945 , both that term and the theories of human "improvement" which it denotes were in wide currency. Francis Galton, a cousin of Darwin, invented the term and launched a movement to improve the human race, or at least to halt its perceived decline, through selective breeding. His ideas spread quickly, and by the 1920s eugenics movements existed all over the world. Eugenics, a movement for social betterment clothed in the mantle of modern science, claimed the allegiance of most genetic scientists and drew supporters from the political right, left, and centre. Unfortunately for that movement, and indeed for much of mankind, eugenics was embraced by Hitler and his Nazi followers, tarnishing its name forever. After the fall of the Third Reich, eugenic ideas quickly lost their cachet, becoming virtually taboo in the United States and Europe, where the term "eugenic" is now used primarily as an epithet.

We should not forget eugenics. Eugenics casts a shadow over the use of genetics in our own era, which promises so much for health, industry, agriculture, and other fields. But that shadow is indistinct. It is often quite unclear whether a new practice in medicine or biotechnology has a eugenic cast, and whether it ought to be opposed on that ground if it does. We can learn much by studying the history of the movement and by engaging in careful moral analysis and assessment of its doctrines.

Eugenics has many lessons:

1. Eugenics is a valuable case study which demonstrates how the prestige of science can be used to disguise the moral premises and motives for a social movement, and how class, racial, and other biases can exert powerful and damaging influence over such a movement while remaining virtually invisible to its advocates. And it is another illustration of the sad thesis that good (or, at least, high-minded) intentions can lead to evil consequences.

2. Eugenics offers a perspective on the practices of our own era, the second moment in history in which the prospect for using the science of heredity to reshape society presents itself. Indeed, critics of certain practices in clinical genetics, and of some contemplated uses for the genetic technology of the future, maintain that these are eugenics in disguise. We must be able to evaluate this claim so that we can avoid the errors and wrongs of the past as we frame public policies for genetics in the future.

3. We should avoid an unthinking rejection of every eugenic thought or value. The fact that eugenicists were in favour of a particular measure or goal is not in itself sufficient reason to oppose it. We need a good analysis of which eugenic aims were wrong-headed, and why. We might judge that some of the questions to which eugenicists proposed answers ought not be ignored, and indeed that they are now given too little attention, in part because of their eugenic associations.

This paper provides both a brief history of the eugenics movement and a moral analysis of some of its tenets. I begin by recounting briefly the rise and fall of this complex international movement. I do not in any way wish to revise the very bad reputation which the eugenics movement currently suffers, and where old-style eugenics is advocated today, as in Singapore ${ }^{1}$ and China, ${ }^{2-4}$ conventional criticisms of these ideas still apply. When we turn to contemporary practices in clinical genetics whose status as "eugenic" is in 
dispute, however, the arguments must be more subtle. I argue that the label "eugenic" does in some instances apply, but that when this is the case the "eugenic" effect or intent of the practices ought not always to engender alarm or opposition.

Though we rightly reject all of the programmes practised or proposed by the eugenics movement in its heyday, I will argue that this retrospective evaluation does not point unequivocally to a rejection of any and all eugenics for the future.

\section{Eugenics past}

THE RISE OF EUGENICS

Though the literature of eugenics extends back to Plato, the modern movement took its cue from biology: first, Darwin's theory of natural selection, with a boost later on from Mendelian genetics. Galton understood that the theory of natural selection had important implications for understanding the development of the human species, and sought to investigate the possibility that talents and virtues of character and personality were inherited along with other traits, offering their bearers advantages in natural selection. Galton coined the term "eugenics" in 1883 , defining it as the "science of improving stock-not only by judicious mating, but whatever tends to give the more suitable races or strains of blood a better chance of prevailing over the less suitable than they otherwise would have had". ${ }^{5}$ His research, enhanced by statistical methods developed as he needed them, convinced him that society's stock of talent could be greatly enlarged if members of favoured families were to increase their rate of childbearing ("positive eugenics"). The balance should be further improved, he believed, by discouraging from reproducing those who had less to offer ("negative eugenics").

Galton's influence was nearly immediate. Darwin declared himself persuaded by his cousin's eugenic arguments, and Galton attracted a number of distinguished disciples. In Germany, the Racial Hygiene Society was formed in Berlin by $1905^{6}$; the English Eugenics Education Society was founded in 1907, with Galton elected honorary president the next year. ${ }^{7}$ In the United Kingdom and the United States, the movement drew on the middle and upper-middle classes; many professionals and academics were attracted to it. $^{7-10}$ During the decades $1890-1920$, eugenic ideas were advanced also in numerous nonEnglish-speaking countries as diverse as Norway, Brazil, and the Soviet Union. Both a research programme and a popular movement, eugenics was taught at leading universities, and received attention in standard biology textbooks.
The popular eugenics movements, meanwhile succeeded in rapidly introducing eugenic ide into public discourse. Accounts of generations $8 \mathrm{f}$ misfits in such "white trash" family lines as the "Jukes" and the "Kallikaks" were widely pub cised, warning that an unwise reproductive ast could wreak havoc for generations. ${ }^{8}$

Following British successes at health exhib tions before the turn of the century, American eugenic organisations took a particular interest in maintaining exhibits and events at state fairs and public expositions. "Fitter Families" competitio $\overrightarrow{\mathrm{Bs}}$ were mounted at state fairs, with governors and senators handing out awards. ${ }^{8}$

The content of the eugenic programmes varifel considerably. Eugenicists tended to agree that the human race was in decline, but they differed over both cause and remedy. The French and Braziliğ eugenics movements were at least as concerned about neonatal care as with heredity, and their hereditarian thinking was Lamarckian-that $\mathrm{s}$, they believed that parents passed on to their chil dren characteristics acquired during their lifetimes. ${ }^{11}{ }^{12}$ Most eugenicists elsewhere accepted Galton's view, buttressed by the "germ plasno hypothesis of August Weismann, that selection rather than environment determined heredi Eugenicists tended to draw from this account the implication that medical care frustrated evolution by permitting the unfit to survive and reprodue (though Darwin and a number of others who held this view none the less continued to suppo humanitarian measures).

Eugenicists differed also in their practic proposals and legislative aims. While action $\dot{\text { क् }}$ behalf of positive eugenics was limited to such mild measures as family allowances, some eugergcists (particularly in the United States and, latê, Germany and Scandinavia) did not hesitate to call for coercive measures, either sexual segregatidis or, later, involuntary sterilisation, to prevent tho imagined to have undesirable genes from propo gating their kind.

In Germany, eugenics became an integna element of medical thinking, which envisioned ${ }_{a}^{a}$ three-way division of health care involving medical care for the individual, public health for the community, and eugenics for the race. ${ }^{13}{ }^{14}$ Euger ics, for some, was an extension of a tradition of social orientation in German medicine that had produced Rudolf Virchow and other pioneers of public health.

Historians have generally followed Daniel Kevles's ${ }^{7}$ classification of eugenicists, at least in England and the United States, as either "maio line" or "reform". In the United States a 
Britain, mainline eugenics was largely (but not exclusively) conservative in political orientation.

Galton was but the first of a long line of eugenicists who believed that those who excelled (at least in fields such as science and literature, where social position was insufficient for advancement) were distinguished from others in their possession of great natural, inherited talent. Indeed, the mainline eugenicists tended to believe that a person's station in life reflected his or her capabilities and could thus be used as an indication of the genes likely to be passed down to subsequent generations. To the extent that eugenics is remembered at all, what is recalled tends to be the "mainline" movement, with its conservative politics and its tendencies towards class bias, racism, and xenophobia, all of which foreshadowed the Nazis'embrace of eugenic doctrines.

In actuality, however, there once were eugenicists all over the political spectrum. The "reform" contingent, often socialists, and including many of the leading figures in the science of human genetics, accepted eugenic goals, but were unsparingly critical of the mainline eugenicists' research, biases, and proposals. Hermann Muller, an American geneticist who later won a Nobel prize for demonstrating the effect of radiation on chromosomes, insisted that natural talent could not be assessed in a society such as the United States, which did not offer equal opportunities for advancement to its citizens; only under socialism could the fit be identified as such, and then encouraged to multiply.

The labels "mainline" and "reform" do not do justice to the great variety of viewpoints and goals associated with the eugenics movements. Indeed, as Diane Paul has observed, one sign of the ubiquity of eugenic thinking was the attempt by parties on all sides of particular social disputes to further their cause by demonstrating that their recommendations would have the strongest eugenic effect. ${ }^{15}$ Eugenics, seen as an avenue for the application of science to social problems, was attractive to some of the architects of the modern welfare state, such as the Progressives in the United States and the Scandinavian Social Democratic parties. ${ }^{16}$

Indeed, much of the opposition to eugenics during that era, at least in Europe, came from the right. The eugenicists' legislative successes in Germany and Scandinavia were not matched in such countries as Poland and Czechoslovakia, even though measures had been proposed there, largely because of the conservative influence in these countries of the Catholic Church. ${ }^{17}$ The Church opposed eugenics in principle (and was virtually the only institution to do so), but this was of a piece with its opposition to abortion and con- traception: then, as now, the Church was opposed to limitations on fertility, and its opponents were often on the left.

To be sure, early eugenicists were also opponents of birth control, since they believed that its use by the upper classes exacerbated the degeneration of the gene pool. But not all eugenicists took this position. The eugenic banner was seized also by feminists, who argued that control over fertility, along with emancipation generally, permitted women to improve the race through sexual selection.

\section{THE NAZI DEBACLE}

Eugenics in Germany, while distinctive in having a medical leadership, had been marked by much the same divergences of opinion as the movements in other countries. Though numerous prominent eugenicists were racist and anti-Semitic, others were avowedly anti-racist (and some were Jews), and a number stood on the political left. ${ }^{6}$ The Nazis imposed a uniformity of viewpoint, securing the allegiance of the many eugenicists who rallied to their cause for a thoroughly racist, nationalist eugenic programme that recognised no limits in the pursuit of "racial hygiene".

Eugenics was central to the entire Nazi enterprise, joined with romantic nativist and racist myths of the pure-bred Nordic. The emphasis on "blood" called for a purifying of the nation's gene pool so that Germans could regain the nobility and greatness of their genetically pure forbears. ${ }^{18}$

As Robert Proctor ${ }^{14}$ and other historians have shown, the subsequent programmes of sterilisation, "euthanasia" of the unfit (a programme that took the lives of tens of thousands of "Aryans," mostly young children), and eventually the Holocaust itself were part of the unfolding of this central idea. The sterilisation and "euthanasia" programmes, which did not initially target Jews and other minorities, were an exercise in negative eugenics designed to improve the native German stock from its degenerated condition. Legislation barring sexual relations between Jews and "Aryans," and ultimately the Holocaust, were intended to prevent further adulteration of the "pure" German nation with inferior genes. Jews and others who contributed evil genes were the disease afflicting the German nation, which Hitler, the physician, would cure.

These measures were complemented by a range of other genetic interventions, ranging from an elaborate system of genetic courts passing judgment on the genetic fitness of those thought to harbour defective genes, to marriage advice clinics, to the Lebensborn breeding programme for SS men and other racially motivated initiatives 
in positive eugenics. ${ }^{6}$ The academic fields of anthropology, biology, and medicine were reformulated in racial and eugenic terms, and the profession of medicine in Germany was compromised by its participation in government programmes of identification, sterilisation, and murder of those deemed unfit. ${ }^{618-20}$

\section{DECLINE AND FALL}

In its first years, Nazi eugenic programmes and propaganda won the acclaim of eugenic leaders in the United States. The Nazis flattered their counterparts overseas by pointing to legislation in California and elsewhere not only as precedents but also as models, and the authors of these statutes toured Germany and filed favourable reports upon their return. ${ }^{21}$ After the Holocaust and the defeat of the Germans, however, eugenicists in most other countries distanced themselves from German eugenics; since the Germans had presented themselves as the most consistent and purposeful of eugenicists, the movement itself fell into general disrepute. American eugenics organisations experienced amnesia over their prewar affinity with their German counterparts, spoke out against racism, and urged Americans to consider eugenics as a source of national strength. Nevertheless, the eugenics societies soon lost their followers; the American society's journal was renamed the fournal of Social Biology, and what had in prewar years been a virtual consensus in favour of eugenics among genetic scientists disappeared within a decade. The movement's offices were shut down, and the Rockefellers and other funding sources turned their attention to related but more reputable concerns, such as world population control, the prevention of birth defects - and to genetics and molecular biology. ${ }^{22}$

There is some controversy over the explanation of the sudden disappearance of eugenics from our national consciousness. The account given in the first histories of the eugenics movement was that eugenics was abandoned as the science of genetics progressed, leaving genetic scientists increasingly dubious of the central factual claims of the movement. A revisionist tradition points to the strikingly rapid repudiation of eugenics by reputable geneticists in the mid-1940s, a period marked not by any sudden increase in scientific knowledge but by the scientists' strong interest in distancing themselves from the Nazis. These accounts have different implications for the future of genetic policy. If eugenics succumbed to the advancement of science, perhaps the lid on its coffin is nailed as tightly shut as it needs to be. If, however, the retreat from eugenics was simply one of fashion, the movement has not been repudiated on the basis of fact or even principle, and we might unthinkingly (or, worse, consciously) return $\bar{F}_{0}$ eugenics when and if fashion changes aga if. Finally, if clinical genetics is simply eugeniz under a different name, we must achieve a cleagr understanding of the morality of both.

\section{Is eugenic doctrine inherently evil?}

The history of the eugenics movement is marked by a sorry record of pseudoscience, prejudice ared bias, and, in its Nazi version, even mass murdë. We can learn from eugenics that at least oge movement dedicated to the betterment of huma $\overline{\overline{\mathrm{z}}}-$ kind through genetic improvement led to terrible wrongs. But must this goal point us in the direction of evil? In the remainder of this essay, my question is whether there was, and is, a molol misjudgment, an inherent wrong, at the heart gf eugenic doctrine; and, if so, in what it consists. The attempt to answer this question presents opportunity to assess the choices open to us in the coming decades of progress in genetics. If we a $\overrightarrow{g e}$ to avoid the errors and sins of the eugenics move ment, we will need an account of what these were. And the same holds true if we are to avoid the converse danger of refraining from justifiabse remedies and interventions because we mistakengy believe them to share the taint of eugenics.

This inquiry is an uneasy hybrid of history moral philosophy. Since our goal is to discegn where the shadow of eugenics falls, the analysis has begun with a (brief) record of what eugenicișts actually believed. But to comment on the appliegbility of their beliefs, goals, and values for the future, we must abstract from their historical co宜text, trying instead to find themes which might apply to our own time and yet which can reasol ably be attributed to the eugenicists of a century ago.

\section{EASY TARGETS}

So much that the eugenicists believed, said, areet did has been repudiated that one need not look to find their "errors". The eugenicists' scientifice claims and pretensions are a case in point. Indeed, present-day warnings of a return to eugenics often amount to cautions over untenable claims fon behavioural genetics, in particular the heritabilien of personality traits, and both genetic essentialis and determinism. Though debate continues such claims - new discoveries of "the gene fo diverse behavioural characteristics appear fro quently, and almost as frequently are later withdrawn - the bulk of the eugenicists' claims of the genetic basis of personality are now believedgo be erroneous. 
Similarly, there are few defenders of the violations of reproductive rights, and rights of bodily integrity, involved in eugenic involuntary sterilisation programmes - to say nothing of eugenic euthanasia, as practised on small numbers of infants in the United States and on a mass scale by the Nazis. ${ }^{23}$ Diane Paul ${ }^{24}$ has pointed to the development of strong guarantees of reproductive autonomy as a key difference between our own era and that of the eugenicists, one which, it would seem, would preclude the kind of artificial selection which the eugenicists had proposed.

Much the same can be said of the class biases and racism which so marked the mainstream eugenics movements in the US and UK (to the extent that one historian defined eugenics as a war on the lower classes). ${ }^{10}$ While these biases certainly persist, anyone in the United States or Britain who openly advocated a eugenic programme that explicitly endorsed such attitudes would be quickly reprimanded.

Each of these attributes of eugenics - genetic determinism, disregard for individual rights, and racial and class bias - is so closely linked to the reputation of eugenics that warnings of a return of eugenics are often simply accusations of one of these fallacies and wrongs. If these were all that eugenics amounted to, the analogy of eugenics to Prohibition in the United States, an historical curiosity of no particular importance for our time, would be sustained, and the present paper could end at this point. Put differently, we might argue that if we try to imagine a eugenics movement from which we remove the class and racial biases, the faith that personality traits were fixed by heredity, and the conviction that the freedom of the individual to decide whether and with whom to procreate must be overridden in the name of genetic improvement, then it is not the eugenics movement we are imagining. For these attributes defined the movement.

This kind of analysis, however, comes at the cost of rejecting the definition of eugenics given by Galton, who coined the term and initiated the movement. Galton's several definitions varied over the years, but they were variations on a simple theme: using our understanding of the laws of heredity to improve the stock of humankind. In itself, this notion is not necessarily committed to genetic determinism, violations of reproductive liberty, class bias or racism. And though common in the eugenics movements of 1883 or 1933 , these beliefs and attitudes also affected other social movements and programmes, and indeed the discourse of the educated classes generally. If we may carry Galton's core notion to the present, presumably more enlightened day, what sort of programme would it entail? And will we find any hint of a eugenic original sin, a wrong present even in Galton's original conception?

\section{Five candidate wrongs}

I will survey five wrongs, or putative wrongs, which might be or have been alleged to be inherent in the core eugenic doctrine of improving the stock of humankind by application of the science of human heredity. Most, I believe, are not good candidates: either they are not inherent, or they are not necessarily wrongs. But in the end, caution towards eugenics is still advised.

\section{(I) REPLACEMENT}

The first candidate wrong faults the core doctrine of eugenics on the grounds that it seeks "better" (or "fortunate") people rather than people who are made "better" (or "fortunate"). This complaint faults eugenics for posing as a doctrine of benevolence. While "human betterment" is the name of eugenics's game, according to this view, it actually betters no humans. No person's diseases are cured, and no individual's intelligence is raised, by eugenic interventions even when (and if) they are successful in their own terms. Instead, the programmes cause the world to be populated by individuals who have these advantages from their beginnings. In essence, eugenics favours healthy people over unhealthy people, and smart ones over stupid ones. That may be acceptable as a basis for choosing friends, or even employees, according to this complaint, but it is not a particularly noble social aspiration. Eugenics, in this view, does not involve any hopes for our fellow human beings, but rather a preference for the sort of fellow human beings we have.

Does this charge identify an inherent wrong in eugenics? I think not. It does locate something inherent in the doctrine - selection is what eugenics was about - but the complaint does not succeed in showing that it is really a wrong. Many social interventions of unquestioned benevolence have unintended effects on the composition of the population. As Derek Parfit ${ }^{25}$ has taught a generation of moral philosophers, this is simply (and trivially) due to the fact that interventions with large-scale effects inevitably affect the circumstances of human reproduction, such as the moments at which people engage in sexual intercourse. This in turn determines who will be born, for when it comes to identity and fertilisation, timing is everything. Each of us is the unique product of the union of a particular sperm and a particular egg; the product of a different pair would be someone else. Macroeconomic interven- 
tions, along with most other large-scale measures, result in different sperm being united, in sexual reproduction, with different eggs, and thus change the cast of characters which will populate that part of the globe in the next generation. Yet good social policies are not a bit objectionable for that reason. It is true that these policies, unlike eugenic programmes, do not aim to determine who will be conceived and born. Nevertheless, the effect is largely the same, and it is noteworthy that they are no less laudable for that.

In any case, this complaint against eugenics proves too much. It would find fault with a woman's decision to marry one suitor rather than another because the first would be the superior parent; or another parent's decision to delay having a child until he or she was financially and emotionally ready to be a good provider and parent; and with parents who discouraged the maternal urges of an unmarried teenage daughter on similar grounds. Yet surely these choices are perfectly defensible. If the "replacement" complaint against eugenics applies to these as well, we must reject its claim to have found a serious moral flaw in that doctrine.

\section{(II) VALUE PLURALISM}

Wilhelm Johannsen, the Danish geneticist, asked in 1917, who was to set the criteria for ideal man: "But what is the ideal? Who shall be responsible for the decision? The complexity of society makes it impossible that one single human type should be the best. We need all different types of humanity." ${ }^{26}$ It is not uncommon to find the eugenicists blamed for promoting a particular conception of human perfection, failing to appreciate the essential plurality of values and ideals of human excellence. Like others, they assumed that the ideal would be similar to themselves, or at least to those whom they most admired. Mainline eugenicists in the UK and US, largely members of the upper-middle professional classes, hoped for a society in which each person would attain their level of virtue, and despised those who failed to display the proper bourgeois values. Nazi racial hygienists, many of whom considered themselves to be of "the Nordic type", valued the Nordic type. Hermann Muller, the socialist geneticist and eugenicist, extolled a wide range of models, including Lenin, Gandhi, and Sun Yat-Sen; surely a heterogeneous group. But all of these were, like Muller himself, exceptionally brilliant men. As the question attributed to Johannsen, a scientist and reluctant eugenicist, demonstrates, the difficulty of defining human perfection was not entirely lost on the eugenicists, but the strident rhetoric of much of the mainline eugenics literature brooked no opposition and admitted to no doubt over wha constituted a "healthy" and virtuous style of life $\overline{\bar{n}}$.

We might suppose, therefore, that what is wronf with eugenics is a denial of the plurality of ideals $\overrightarrow{\text { of }}$ a valuable human life. Eugenics, according to this complaint, must inevitably impose a particula vision of human perfection. Those who urge eugenics show a limitation of moral understan ing and fail to realise that theirs is but one of og multiplicity of such visions, shaped differently by diverse cultural traditions and circumstances and by moral reason. This limitation in understanding is potentially harmful to people of the sort the eugenicists hope not to reproduce, since it denie⿸户㔾 to them the self respect which accompanies the aspiration to raise children in one's own image should this be the desire of those parents.

Is this the wrong, or a wrong, inherent eugenics? Understood as a claim about the historical eugenics movement, as opposed to the pure Galtonian ideal, I believe that the complai is partly right but mostly wrong. If directed to the ideal itself, as it might be realised in the future, is again mostly wrong. The complaint is rigke about the historical movement in that the mainline eugenicists made no secret of their fer cious, and in some cases, murderous, disdain $\mathrm{f}$ the very kinds of people whose fertility the wished to curb. Davenport ${ }^{27}$ celebrated the dea禹 of a child born to a prostitute:

"I recall the impassioned appeal of a sociologist for assistance in stopping the frightful mortali among the children of prostitutes. But the daughe ters of prostitutes have hardly one chance in two ogf being able to react otherwise than their motheris. Why must we start an expensive campaign to kee alive those who, were they intelligent enough, might well curse us for having intervened on the behalf? Is not death nature's great blessing to th race?"

Oliver W Holmes, America's celebrated Suprend Court judge, wanted no more of the soश represented by the petitioner Carrie Buck, thl third of "three generations of imbeciles" who hat propagated "enough", 28 and in refusing her petition to remain fertile, opened the floodgates of sterilisation in American institutions. ${ }^{29}$

Today, we rightly abhor these sentiments, and, of course, the even more repugnant judgmen about human "types" which animated the Naze Nevertheless, the failure to respect the plurality of values was not the central problem, even of mairoline eugenics. The traits which the eugenicises believed heritable and worthy of cultivation wege ones which are valued by people with widely vare ing ideals of personal development, plan of lifes; 
and family structure. Though some eugenicists did believe there to be particular genes for drunkenness, "shiftlessness", and the like, in the main the eugenicists focused on a very short list of traits about which there is little controversy. Intelligence dominated the list, or was the only item on it; selfcontrol and a few other very general virtues were sometimes added. For many eugenicists, a long list of objectionable phenotypic traits, ranging from sloth to immorality, were the result of the lack of the genes thought to be necessary for these cardinal virtues. There is little real dispute over the value of these all-purpose talents, even among those who reject the class snobbery of the mainline eugenicists. Whatever one's favoured pursuit or style of living, intelligence and selfcontrol help one make the most of it. When we consider a future eugenics programme, based on Galton's core idea, we can easily envision one that would focus exclusively on these all-purpose advantages. Value pluralism need not be an issue.

It remains true that the mainline eugenicists were anything but tolerant of personal and social ideals which differed from their own. They favoured breeding humans with an eye to intelligence and self-control because they thought that these traits were necessary if a person were to lead a "proper" kind of life, ie one like their own. Claims of this kind, for example that the poor are too stupid to understand the difference between right and wrong, or to exercise the restraint necessary for the nuclear family, resurface today in such works as Herrnstein and Murray's book, The Bell Curve..$^{30}$ But the transmissible characters targeted by the intervention remains one on which there is agreement regardless of differing ideals of human perfection. Value pluralism could become an issue in eugenics, even if it is not inherent in the core idea. Deaf parents who wish to abort fetuses which do not test positive for inherited deafness, and dwarf parents who want only a child with the gene for achondroplasia, hold unconventional values, and their freedom to act on them is at issue in the ethics of clinical genetics. The European parliamentary panel on genetic engineering, headed by a Green representative to the German Bundestag, held that genetic screening requires us to decide what are "normal and abnormal, acceptable and unacceptable, viable and nonviable forms of the genetic make-up of individual human beings before and after birth". ${ }^{31}$ If we ever acquire an ability to influence personality and character through genetic choice or manipulation - to choose, for example between aggressive and gentle dispositions - this debate will be of crucial importance.
Everyone supports the goal of health, and though we do not share precisely the same concepts of health (and of disability), diversity of opinion is limited to a few disputed instances. When genetic interventions are aimed at enhancing the genome of the healthy individual, however, the scope of potential disagreement is nearly unlimited. Some of us may live long enough to see the genetic advances which will occasion such debates. Nevertheless, eugenic programmes could avoid the problem of value pluralism simply by limiting its focus to those human characters on whose desirability there is universal or widespread agreement.

\section{(III) STATISM}

In a recent address, James Watson ${ }^{32}$ reviewed the odious history and possible future of eugenics and concluded that the most important safeguard was to eliminate any role for the state. He provided a strong case. The great wrongs visited on vulnerable people in the name of eugenics - institutionalisation, sexual segregation, sterilisation, and, in Germany, murder on a mass scale - could not have occurred without the agency of the state. In England, where the state's role was minimal, eugenics may have been offensive but it did not violate individual rights (though some of its supporters hoped for eventual acceptance of involuntary sterilisation)..$^{33}$

Since involuntary sterilisation, supported by legislation, is perhaps the most notorious wrong committed by eugenicists aside from the Nazi crimes, Watson's emphasis on the role of the state is understandable. Still, many would take issue with his contention that the state is the chief enemy. Critics of current practices in clinical genetics claim that counsellors and physicians are often, even routinely, directive towards some clients, and that this subtle coercion continues without the explicit backing of the state. Moreover, what Troy Duster" ${ }^{34}$ has called "backdoor eugenics" threatens to visit harm on the genetically disfavoured through the cumulative effect of many private decisions on the part of employers, insurers, and prospective parents. As Robert Wachbroit ${ }^{35}$ has observed, government and society might conceivably switch roles, with the former intervening in private choice in order to preserve the liberties and wellbeing of those whose genes threaten disease or disability. In such a scenario, denying a role to the state might hasten eugenic evils rather than protecting against them. If the "backdoor" concern is justified, we ought not to conclude that the wrongs of eugenics can be avoided as long as the state forswears any eugenic intent. 
Thus a strong state role is not essential for a eugenic programme. True, it may be difficult to win compliance with eugenic prescriptions without the long arm of the law. That is why Galton, imagining a fully voluntary regime, mused that eugenics might have to be instated as a civil religion in order to induce members of society to make the sacrifices required. Eugenics never attained this status, whether in the UK or elsewhere (not even in contemporary Singapore, where the head of state has been an enthusiast). The British eugenics movement was no less "eugenic" for being a citizen's movement relying on voluntary measures, and from this fact it follows that statism is not a source of wrongs inherent in the core of the eugenic programme.

\section{(IV) "COLLECTIVISM"}

An alternative analysis locates the wrong inherent in eugenics in its concern for the genetic wellbeing of the group rather than that of the individual. In this view, concern for the individual is benign. Indeed, genetic intervention might be mandatory, from the moral point of view, in certain cases. Parents who knowingly bring into being children who suffer agonising and deadly defects might be accused of "wrongful life". The fateful turn towards eugenics occurs, in this view, when we widen our interest from the individual child to the group, hoping not that our own sons and daughters will be healthy but that the population's gene pool will be improved.

This is a "collectivist" vision in the sense that the object of our concern is the group as such, while our concern with the individuals who constitute the group is primarily in the contribution which they might make towards the wellbeing of the collective.

Narrowly defined, "collectivism" doctrines are those according to which interests inhere in the collective entity or group in addition to the group's members' interests. Much of eugenic writing, whether "mainline" or "reform", was collectivist in this sense. More loosely, we might understand the label "collectivist" for eugenic doctrines or policies which locate interests only in individuals, but which condone trading of the wellbeing of some for that of others. Social Democratic eugenicists in Scandinavia, for example, were often candid in noting the burden imposed by eugenic sterilisation upon those sterilised, but justified the practice in terms of the reduced burden of dependents. ${ }^{16}$

According to this understanding of where the wrong in eugenics lies, a bright line can be drawn here, one that both distinguishes medical genetics from eugenics and locates the wrong inherent in the latter. If we draw the line here, we reject the notion that parents who seek "the perfect bab? are themselves engaging in eugenics. This undef? standing of eugenics provides a green light $\overrightarrow{\mathrm{H}}$ medical genetics, which can be permitted to conttinue its rapid development without the worry the it is revisiting the errors of the past.

But what, precisely, is the wrong which this vien attributes to eugenics? Consider these three state ments:

1a. I favour a genetic intervention because I wa $\vec{A}$ my child to have the "best" (healthiest, et genes.

1b. We favour genetic interventions (on behalf $\mathbb{R}_{\mathrm{R}}$ each of us) because we want our children \& have the "best" (healthiest, etc) genes.

1c. I favour genetic interventions (for each persan in our group) because I want our children have the "best" (healthiest, etc) genes.

If $1 \mathrm{a}$ is morally acceptable, surely it doesn become wrong when voiced by several people (in the form of $1 \mathrm{~b}$ ). And how can I be faulted beg endorsing that group's hope (1c)? $1 \mathrm{~b}$ and $1 \mathrm{c}$ are merely the aggregate of many instances of $1 \mathrm{a}$. Ore might expect to hear 1c uttered by, say, a heal official, or a legislator who sponsors a measufe which would provide genetic services to larg numbers of people. Concern for the welfare of large numbers of people is part of such a person job description.

Consider, in contrast:

2. The sum total of benefits involved in programme of genetic interventions will be greater than the costs.

Here we seem to come closer to a "collectivist view, for 2 does not claim that the benefits for each individual might outweigh the costs. It leaves open the possibility that some may lose while othe benefit, promising only that the magnitude of the latter will be greater.

However, this appearance may, I believe, be misleading. Statements such as 2 are often made by way of justifying the use of public funds. The point of the intervention in such cases is not save public money, for the professed (and, we ma assume, the actual) goal is to ensure that as mang children as possible are born with genes which make their lives go well. Given the endles competition which exists for public funds, how ever laudable their purpose, it always helps if ore can argue that the net social cost is zero or bettex. This calculation has been a trump card in debates over health care allocation when played 
advocates for perinatal medical care, and it might apply equally well for a programme aiming to provide better genes.

Consider, finally:

3. A programme of genetic intervention will limit the number of people who are a burden to others.

Have we, with this step, crossed the line to the "collectivist" position? And if so, does this claim partake of eugenics's original sin? The answer, I believe, is not as straightforward as it might appear.

We might begin by noting that if this claim does in fact put us on the wrong side of that imaginary moral line, we may have stepped over it a bit earlier. I just argued that a cost-benefit calculation, such as 2 , need not be motivated by a wish to save society some money. But of course it could be. This might be the real goal in a particular instance even when the advocates of a programme offer it merely as a justification for the use of public funds. In either case, 2 would be in the same moral company as 3 .

But is 3 "collectivist", where we understand that term as betraying concern for individuals only insofar as they add to or detract from the wellbeing of the group, and is it morally repugnant for that reason? We should note, first, that 3 is not necessarily "collectivist" in the narrow sense defined above, according to which the beneficiary is a collective entity, be it the Reich, the Revolution, or the Race, for which no sacrifice of individual wellbeing can be too great. Nazi eugenics, of course, was a collectivism of this other sort, obsessed with the glory of the reified Volk. But that is no part of the original Galtonian eugenics, at least at its core.

More to the point, the core notion of eugenics does not necessarily ask for sacrifice of any sort. Programmes which isolated or sterilised tens of thousands of people, and of course those which resorted to murder, imposed the greatest of sacrifices, but Galton's original proposal did not call for these measures. English eugenics, for all their concerns over the excess fertility of the unfit, generally proposed voluntary curbs on reproduction. ${ }^{7}$

In any case, the sacrifice which a eugenic programme might ask of prospective parents is likely to be much less onerous as technology develops. In Galton's day, eugenics was mainly concerned with who mated with whom and how many children resulted. For the "unfit", childlessness (even if voluntary) was the price of eugenic correctness. Today, a eugenic principle might call for prospective parents to screen pregnancies so that the children they bring to term have the greatest feasible genetic advantages. Tomorrow, these same parents might be encouraged to avail themselves of genetic interventions to cure and to enhance. Excepting perhaps the fetuses which are aborted as a result of such a programme, no one would be asked to make sacrifices. Because parents almost always seek advantages for their children - health above all - there is a congruence between a eugenicist's concern for the public and a parent's concern for his or her child. Where there is not, a voluntary programme would leave the decision to the parent. The potential child whose conception or birth is avoided by this intervention does not count in the moral calculation which "collectivism" insists we make. Common sense must concur.

Nevertheless, this kind of eugenic programme might claim some actual, living victims. As disability-rights advocates have insisted, it is difficult to argue for public programmes on the basis of claims like 3 without suggesting, in the same act of speech, that the existence of people who are dependent on others is a fact to be regretted; and this sends the message that these lives are not, in some sense, valuable. I will not take the trouble to argue that this sentiment is reprehensible and that the opposite message ought to be the cornerstone of public policy, both in genetics and elsewhere. Every person is valuable, and not only for any contribution which he or she might make to others. The rhetoric of mainline eugenics in the UK and the US, with its denunciations of "human filth" and "human rubbish," are justification enough for the abysmal reputation of these movements, even apart from the programmes of mass sterilisation and murder which followed in their wake. Perhaps we have found, therefore, some hint of an "original sin" of eugenics. In the series $1 a-1 b-1 c-2-3$, it occurs somewhere between 2 and 3 , when we begin to calculate the value of genetic improvement not in terms of the wellbeing of the individual whose genes are less likely to cause that individual to suffer, and more likely to enhance that individual's wellbeing, but for the effect which the existence of that individual might have on the wellbeing of others. But this is not quite "collectivism", and I would urge that this wrong, if it is that, be given a different rubric: unfairness.

\section{(v) FAIRNESS}

In the United States and England (though not in Germany), the fields of eugenics and public health involved different people, expert professions, journals, and aims. But the two movements shared many assumptions and attitudes. As Charlotte Muller noted in her insightful review, the gross 
differences in health status across racial and income lines tended to be explained in terms of heredity. ${ }^{36}$ Burdens imposed by eugenics were justified by the analogy to public health, as Justice Holmes did, when he compared sterilisation to vaccination. ${ }^{28}$

Martin Pernick ${ }^{37}$ has noted extensive overlap even in the jargon of the two fields, each of which resorted to "isolation" and "sterilisation" of the individuals who were thought to pose threats to the wellbeing of the public. Eugenics was often described in medical terms, ${ }^{38}$ for example as an effort to prevent the spread of (genetic) disease from generation to generation. Hitler was lauded as the great doctor of the German nation, rescuing the Aryan gene pool from the genetic disease introduced by Jewish infestation. ${ }^{14}$

Public health had one more characteristic in common with eugenics: it created and struggled with many of the same moral problems. A persisting theme in the ethics of public health is the greater effectiveness often achievable if the interests of some are sacrificed to the interests of others. Despite the great protection Americans enjoy in the inviolability of the person, public health requirements sometimes have priority, as Holmes's reference to vaccination policy shows. How to balance these benefits and burdens is a question of distributive justice which public health programmes will always have to face.

Despite the fact that genetic technology will permit some eugenic goals to be achieved without burdening prospective parents, a public policy of providing "better" genes to future generations is bound to impose social costs. Even a fully voluntary, medically oriented programme-what is called "clinical genetics" today and which strenuously avoids any association with the eugenics of old-must answer to advocates for the disabled who claim that the wellbeing of the disabled is put at risk when genetic screening programmes try to ensure that none with their disabilities will be conceived or born. Bioethicists have warned of decreasing tolerance of differences, once we acquire the power to choose "the best", and this intolerance might impose social sanctions on those who declined to make such choices.

More concretely, it is not unreasonable to fear that if it once again becomes respectable to advocate eugenics, the wrongs of the past will return in full force. I have argued that eugenics, considered as a set of principles, need not assume genetic determinism, nor advocate or condone racism or class bias. In actual practice, however, what guarantee can there be that a eugenic programme would not be guided by these still prevalent beliefs and attitudes? Similarly, we could imagine, in principle, a eugenic programme which avoiф\$ coercive measures, particularly sterilisation, b $\overline{\text { fit }}$ what assurance do we have that these measures might not eventually be viewed as justified, if pu原 lic policy seeks to provide "better genes" and the benefits they might bring to society?

The ethics of eugenics and the ethics of publ health, therefore, are closely related. Neith $\overrightarrow{8}$, unfortunately, has received the same attention as the ethics of personal health care. What standard of justice should be used in guiding any ne. eugenics? The first pages of Rawls's $A$ Theory df fustice include this famous passage:

“ ... Each person possesses an inviolabiliåy founded on justice that even the welfare of sociecty as a whole cannot override. For this reason justiez denies that the loss of freedom for some is made right by a greater good shared by others. It dogs not allow that the sacrifices imposed on a few are outweighed by the larger sum of advantages enjoyed by many. Therefore in a just society the liberties of equal citizenship are taken as settled, the rights secured by justice are not subject political bargaining or to the calculus of social interests." 39

This is not a bad starting position: public policy genetics, whether or not it is termed eugenis, ought not to infringe personal liberty. But thos does not necessarily call on us to avoid any risk $\vec{g} f$ burdening some individuals for the sake of the genetic wellbeing of future generations. I am ng personally persuaded, for example, that the threat of stigmatising the disabled requires us abandon the effort to ensure that future gener tions are free of avoidable disability. But this kingl of concern points us to a valid question of justice and also to an irony.

The point about justice is that genetic benefiss provided in services used by a particular pair $\bar{\phi} f$ parents may have adverse effects on others, aref we are bound to reflect on the fairness of the resulting distribution of benefits and burdens. Tire irony is that this very admonition pulls us toward\$ and possibly over, the bright line which boun that which we identified as a possible wrorg inherent in the core notion of eugenics. This liae is crossed when the goal of our genetic intervertion is not only the wellbeing of the individual, but also the effect on others of bringing this persol into the world. If we are required by distributige justice to consider the effects upon all members $\mathrm{ff}$ the community when we contemplate geneti̊n interventions, this moral imperative is in effeet telling us to consider not only the benefit of ca contemplated intervention for a particular ind vidual, but also for others. If there is a wro 
inherent in the core Galtonian eugenic project, it surely has to do with this very move, which takes us beyond the "medical" or "clinical" focus on the patient at hand (or, in the case of procreation, on the child to be) to the society as a whole. In the latter, wider view, the patient recedes from the foreground and a moral judgment is made on the basis of a calculation which takes into account the claims of many.

\section{Conclusion}

Where does the shadow of eugenics fall? Is there a wrong inherent in the core Galtonian eugenic programme? And what guidance might the answer to this question give us in deploying the resources of the new genetics?

One respectable position which I have not taken up directly in the above is that the core notion of eugenics may be benign, because it is trivial. No one objects in principle, according to this view, to using what we know of the science of heredity to improve the chances of future generations for achieving greater wellbeing. What rouses passionate debate are the means to be used; or the problem of value pluralism; or one of the other "easy targets" which are discussed in II, above.

Perhaps so. Much of the controversy over China's law on maternal and infant health care has indeed focused on its apparent threat of coercion, rather than its goal of a generation of healthy Chinese children. ${ }^{40}$ But clearly some who express concern about a return of eugenics in the West are worried by the move from "medical" concern for the individual to "eugenic" ambitions for improving the gene pool in general, even if coercion is not proposed as a means to this end. Perhaps the worry is roused by the fact that this move was accompanied, early in this century, by great wrongs, harms justified by the greater good, and the fear that once the "collective" goal is established, the demand for sacrifices by individuals will not be long in coming. In some cases, however, the complaint against "eugenics" seems to be lodged against those who profess concern for the genes of humankind apart from the genes of one individual patient, whether or not the broader concern be advanced by coercion or other harms.

I do not see that much hangs on the resolution of this question. In either case, we can draw the important (if obvious) lesson that progress in genetics must pay attention to these questions of distributive justice. This very general, yet morally crucial, requirement ought to guide us now, as we decide which programmes of genetic testing and screening to undertake, and also in the future, as we contemplate the possibility of refashioning the human genome to engineer a new, perhaps improved version of homo sapiens. Done justly, the genetic wellbeing of "the group" is a proper object of concern. The question of moral importance is not whether this constitutes eugenics; it is whether it can be done fairly and justly. It wasn't, the last time it was tried.

\section{Credits and acknowledgements}

This essay overlaps my contribution to Alison Thompson and Ruth Chadwick's book, Genetic Information: Acquisition, Access, and Control, London: Plenum, 1998; my "Eugenic values", in Science in Context, 1998; 10:3-4; and parts of a forthcoming book (tentatively titled Genes and Social Fustice), co-authored by Allen Buchanan, Dan Brock, Norman Daniels and myself, to be published by Cambridge University Press. The author is indebted to Diane Paul for help with sources and interpretations.

Daniel Wikler, PhD, is Professor in the Program in Medical Ethics, Department of History of Medicine and in the Department of Philosophy, University of Wisconsin, USA.

\section{References}

1 Chan CK, Chee HL. Singapore 1984: breeding for Big Brother. In: Chee HL, Chan CK, eds. Designer genes: IQ, ideology, and biology. Kuala Lumpur: Institute for Social Analysis, 1984: 4-13.

2 Beardsley T. China syndrome: China's eugenics law makes trouble for science and business. Scientific American 1997;Mar: 33-4.

3 Dong-Sheng S. Popularizing the knowledge of eugenics and advocating optimal births vigorously. Beijing: Renkou Yanjiu (Population Research) 1981;4:37-41.

4 Wertz D. Eugenics: alive and well in China. The Gene Letter 1996;I.

5 Galton F. Inquiries into human faculty and its development. London: J M Dent and Sons, 1883.

6 Weindling P. Health, race and german politics between national unification and nazism 1870-1945. Cambridge: Cambridge University Press, 1989.

7 Kevles DJ. In the name of eugenics. Berkeley: University of California Press, 1985:590.

8 Rafter NH. White trash: the eugenic family studies 1877-1919. Boston: Northeastern University Press, 1988.

9 MacKenzie D. Eugenics in Britain. Social Studies of Science 1976;6: 499-532.

10 Mazumdar PMH. Eugenics, human genetics and human failings: the eugenics society, its sources and its critics in Britain. London: Routledge, 1992.

11 Schneider W. The eugenics movement in France, 1890-1940. In: Adams M, ed. The well-born science. Oxford: Oxford University Press, 1990.

12 Stepan NL. The hour of eugenics: race, gender and nation in Latin America. Ithaca: Cornell University Press, 1991.

13 Weiss S. The race hygiene movement in Germany. Osiris 1987; 3:193-236.

14 Proctor R. Racial hygiene: medicine under the Nazis. Cambridge: Harvard University Press, 1988.

15 Paul DB. Controlling human heredity. New York: Academic Press, 1995.

16 Broberg G, Roll-Hansen N. Eugenics and the welfare state: sterilization policy in Denmark, Sweden, Norway, and Finland. East Lansing: Michigan State University Press, 1996.

17 Roll-Hansen N. Geneticists and the Eugenics Movement in Scandinavia. British fournal for the History of Science. 1989;22: 335-46.

18 Burleigh M, Wippermann W. The racial state: Germany 1933-1945. Cambridge: Cambridge University Press, 1991. 
19 Aly G, Chroust P, Pross C. Cleansing the Fatherland: Nazi medicine and racial hygiene. Baltimore: Johns Hopkins University Press, 1994.

20 Wikler D, Barondess J. Bioethics and anti-bioethics in Germany: what must we remember? Kennedy Institute of Ethics fournal 1993;3:39-55.

21 Kuhl S. The Nazi connection: eugenics, American racism, and National Socialism. Oxford: Oxford University Press, 1994.

22 Paul DB. The Rockefeller Foundation and the origins of Behavior Genetics. In: K Benson et al. The expansion of American biology. New Brunswick: Rutgers University Press, 1991.

23 Pernick M. The black stork. Oxford: Oxford University Press, 1996.

24 Paul DB. Controlling human heredity. New York: Academic Press, 1995.

25 Parfit D. Reasons and persons. Oxford: Oxford University Press, 1984.

26 Hansen BS. Something rotten in the state of Denmark: eugenics and the ascent of the welfare state. See reference 16: 9-76.

27 Davenport $C$. The eugenics programme and progress in its achievement. In: Morton A, Aldrich et al, eds. Eugenics: twelve university lectures. New York: Dodd, Mead and Co, 1922.

28 Holmes OW. Opinion in Buck v Bell, 1927, 274 US 205, 207.

29 Reilly PR. The surgical solution: a history of involuntary sterilization in the United States. Baltimore: Johns Hopkins University Press, 1991.
30 Herrnstein RJ, Murray C. The bell curve. New York: Free Pre\$ss, 1994.

31 Quoted in Kevles DJ. Out of eugenics: the historical politics $\overline{\bar{\sigma}}$. the human genome. In: Kevles DJ, Hood L, eds. The codenf codes. Cambridge: Harvard University Press, 1992.

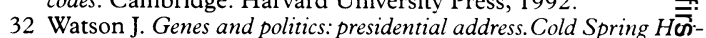
bor Laboratory annual report, 1996. Cold Spring Harbor, New York: Cold Spring Harbor Laboratory, 1997.

33 King D, Hansen R. Experts at work: state autonomy, so learning and eugenic sterilization in 1930s Britain. fourna $\overline{\text { Dof } f}$ Political Science 1999;29:133-63 (in press)

34 Duster T. Backdoor to eugenics. New York: Routledge, 1990. ه

35 Wachbroit $\mathrm{R}$. What is wrong with eugenics? $Q Q$ Report from Institute for Philosophy and Public Policy 1987;7:6-8.

36 Muller C. A window on the past: the position of the client $\vec{b}$ twentieth century public health thought and practice. Americanl fournal of Public Health 1985;75,5:470-5.

37 Pernick M. Eugenics and public health in American histog American fournal of Public Health 1997;87:1767-72.

38 Kamrat-Lang D. Healing society: medical language in Ame्त्रेcan eugenics. Science in context 1995;8:175-96.

39 Rawls J. A theory of justice. Cambridge: Harvard Universin. Press, 1971:3-4.

40 Anonymous [editorial]. China's misconception of eugenirs Nature 1994;367:1-2. 